\title{
La presencia de payasos reduce la ansiedad preoperatoria en niños
}

\author{
The presence of clowns reduces preoperative anxiety in children
}

Vagnoli L y col. Pediatrics 2005;116:e563-7.

\section{Objetivo}

Evaluar si la presencia de payasos disminuye la ansiedad preoperatoria de los niños y los padres durante la inducción anestésica. Determinar la reacción del equipo médico a su presencia en el quirófano.

\section{Diseño}

Ensayo clínico aleatorizado.

\section{Lugar}

Hospital de Niños Anna Meyer, Florencia, Italia.

\section{Pacientes}

Participaron 40 niños de 5 a 12 años que iban a ser operados de cirugías menores con alta en el día.

\section{Intervención}

Aleatorización a "grupo payaso" (GP) en el que los niños fueron acompañados por un padre y los payasos y a grupo control, en el que sólo eran acompañados por un padre. En el GP, dos payasos estuvieron con lo niños en la sala de espera durante 30 minutos aproximadamente y acompañaron al niño y al padre a la sala de inducción permaneciendo con ellos otros 15 minutos. Los métodos de distracción utilizados por los payasos dependían de la edad del niño: trucos de magia, chistes, música, títeres, burbujas, etc.

\section{Medición de resultados principales}

La ansiedad en los niños en el período preoperatorio se midió con una escala de ansiedad preoperatoria de Yale modificada y la ansiedad parental con la State-Trait Ansiety Inventory. Niños y padres fueron evaluados en la sala de espera y luego en la sala de inducción. Además, se evaluó la opinión de los profesionales de la salud sobre la presencia de payasos durante la inducción anestésica y se realizó un cuestionario de autoevaluación a los payasos, sobre su interacción con el niño.

\section{Resultados principales}

Se describen en la tabla 1

Tabla 1. Ansiedad preoperatoria de padres y niños

\begin{tabular}{l|c|c|c}
$\begin{array}{c}\text { Ansiedad } \\
\text { preoperatoria }\end{array}$ & $\begin{array}{c}\text { Grupo Control } \\
\text { (Media DE) }\end{array}$ & $\begin{array}{c}\text { Grupo Payaso } \\
\text { (Media DE) }\end{array}$ & P \\
\hline $\begin{array}{l}\text { Niños en la sala de } \\
\text { espera }\end{array}$ & $35,95 \pm 15,64$ & $30,95 \pm 11,34$ & 0,254 \\
\hline Niños en la inducción & $68,25 \pm 28,42$ & $37,50 \pm 21,48$ & 0,000 \\
\hline Padres (State) & $77,85 \pm 19,19$ & $73,10 \pm 24,96$ & 0,504 \\
\hline Padres (Trait) & $53,25 \pm 24,39$ & $41,45 \pm 22,11$ & 0,117 \\
\hline
\end{tabular}

El equipo médico consideró beneficioso para el chico la presencia de los payasos pero se oponía a continuar con el programa debido a que percibió interferencia con los procedimientos.

\section{Conclusiones}

La presencia de payasos junto con los padres es efectiva para manejar la ansiedad de los niños durante la inducción anestésica. La resistencia del personal médico hace difícil la inserción de estos programas en la sala de operaciones.

Palabras clave: analgesia, anestesiología, ansiedad, estrés parental, impacto psicológico.

Key words: analgesia, anestesiology, axiety, parental stress, psycological impact.

Fuente de financiamiento: Fundación Anna Meyer.

\section{Comentario}

La ansiedad es una emoción normal frente a situaciones potencialmente peligrosas y de incertidumbre $e^{1,2,3}$. Lo patológico es no sentir angustia frente a una amenaza ${ }^{2}$. Un cierto nivel de angustia permite a la persona anticipar las cosas que pueden sucederle y ensayar con el pensamiento diversas formas de acción y de respuesta ${ }^{2}$. En ciertas circunstancias, la persona puede no tolerar angustias demasiado intensas y desorganizarse, es decir, perder el control de la acción ${ }^{2}$. Preparar a una persona, niño o adulto para un acto médico es angustiarlo por adelantado, dosificadamente, para que pueda preguntar por las consecuencias, para evitar fantasías absurdas, para que no se sorprenda, ni se desorganice ${ }^{2}$.

El humor tiene efectos positivos sobre la salud mental y física, mejora la función inmune, la tolerancia al dolor, el estrés relacionado a enfermedades potencialmente fatales. ${ }^{4-6}$ El artículo demuestra la eficacia de los payasos en disminuir la ansiedad preoperatoria de padres y chicos. Lo que no está tan claro es si esto se asocia a menores complicaciones posquirúrgicas y estrés postraumático o si no sería más eficaz una adecuada psicoprofilaxis prequirúrgica.

No es un dato menor que el equipo vea beneficioso para el chico la reducción de la ansiedad pero sienta que los payasos interfieren en su rutina. Los motivos referidos son la distracción de ellos durante los procedimientos, la tardanza en la inducción y la interferencia en la relación médico-paciente. El área quirúrgica tiene normas muy estrictas y tal vez, la presencia de payasos provoque confusión sobre la seriedad del trabajo médico y se malentienda que la posibilidad de reírse pueda conducir a la relajación de las normas de cuidado del paciente. Sería necesario medir la cantidad de errores por distracción del personal y evaluar si esto aumenta el riesgo anestésico.

\section{Conclusiones del comentador}

Desde el punto de vista del niño, ante una situación estresante inevitable y además por el bien de su salud, la estrategia distractoria podría ser de mucha ayuda. ¿Podría hacerla el mismo equipo de salud?

A la hora de tomar una decisión, recordemos que el único fin de la medicina asistencial es el bien del paciente y nunca la preservación de un dogma técnico o de la verdad científica?.

Juan Pablo Mouesca [ Médico especialista en Pediatría. Monte Grande. Provincia de Buenos Aires. ]

Mouesca JP. La presencia de payasos disminuye la ansiedad preoperatoria de padres y niños. Evid. actual. práct. ambul; 10(1):5, ene-feb.2007. Comentado de: Vagnoli L, Caprilli S, Robiglio A y Messeri A. Clown Doctors as a Treatment for Preoperative Anxiety in Children: A randomized, prospective study. Pediatrics 2005;116:e563-7. PMID: 16199685. Disponible en URL: http://pediatrics.aappublications.org/cgi/reprint/116/4/e563

\section{Referencia}

1. De Ajuariaguerra J. La ansiedad en el niño. En: Manual de Psiquiatria infantil. 4º Edición. Ed. Masson Barcelona.1993. 17. 2: 616.

2. Molina Peralta A. Respuestas que indican contacto con la angustia y el dolor. En: La comunicación con lo padres en el servicio de Terapia intensiva pediatrica. Universidad Central de Venezuela. Caracas. 1989. 4: 48-49.

3. LemperiereTh, Féline A. Estados de ansiedad y fóbicos. En: Manual de Psiquiatria. Ed. Masson Barcelona.1989. 7: 79

4. Bennett MP. The effect of mirthful laughter on stress and natural killer cell activity. Altern Ther Health Med. 2003;9(2):38 -45

5. Weisenberg M, Raz T, Hener T. The influence of film-induced mood on pain perception. Pain. 1998;76:365 -375[CrossRef][ISI][Medline]

6. Fry WF. The physiologic effects of humor, mirth, and laughter. JAMA. 1992;267:1857 -1858[CrossRef][Medline]

7. Escardó F. Moral para médicos. Fundasap. Buenos Aires. 2004. 2:31. 